\title{
Bergman as a Master of Expression Interview with Jan Holmberg
}

\author{
Karolína Stehlíková
}

Jan Holmberg (jan.holmberg@ingmarbergman.se) is a film scholar and since 2010 the $\mathrm{CEO}$ of the Ingmar Bergman Foundation (Stiftelsen Ingmar Bergman), which administers, preserves and distributes information on Ingmar Bergman and his work. Jan Holmberg was the head of programming in the Swedish Cinematheque between 2002 and 2004. He is an author of number of studies published in books devoted to the Swedish film, i.e. 'Censorship in Sweden' in Swedish Film: An Introduction and Reader (edited by Mariah Larsson and Anders Marklund, Nordic Academic Press, 2010) or 'Closing in: Telescopes, Early Cinema and the Technological Conditions of De-distancing' in Moving Images. From Edison to the Webcam (edited by John Fullerton and Astrid Söderbergh Widding, John Libbey Publishing, 2016). In 2018, he published a book Författaren Ingmar Bergman (Ingmar Bergman, The Writer) where he explores the writing of Ingmar Bergman as a primary form of his expression.

In 2017, Jan Holmberg held lectures devoted to the history of Swedish film at The Film School in Uherské Hradiště. In 2018, he presented Bergman as a writer and a theatre director at The Theatre Week in Prague. The following interview was carried out as an e-mail conversation in September 2018.

[KS] Jan Holmberg, you are the CEO of The Ingmar Bergman Foundation which administrates one of the world's most comprehensive personal archives for an individual filmmaker' to quote the foundation's webpage. Can you describe the nature of the material the archive keeps?

[JH] The archives contain virtually everything of Bergman's work-related materials such as manuscripts in every stage from the first draft over the hand-written original to finished shooting scripts; some 10.000 letters to and from IB; contracts; etc. And also some less work-related objects such as private photo albums, and much more.

[KS] I suppose most of the archived material is in Swedish. Are there any parts of the archive in other languages (i. e. correspondence, material related to Bergman's stay in Germany etc.)?

[JH] Yes, you're right, I estimate some $90 \%$ of the written materials are in Swedish. The rest (letters, agreements, translated shooting scripts) are mostly in German and English. 


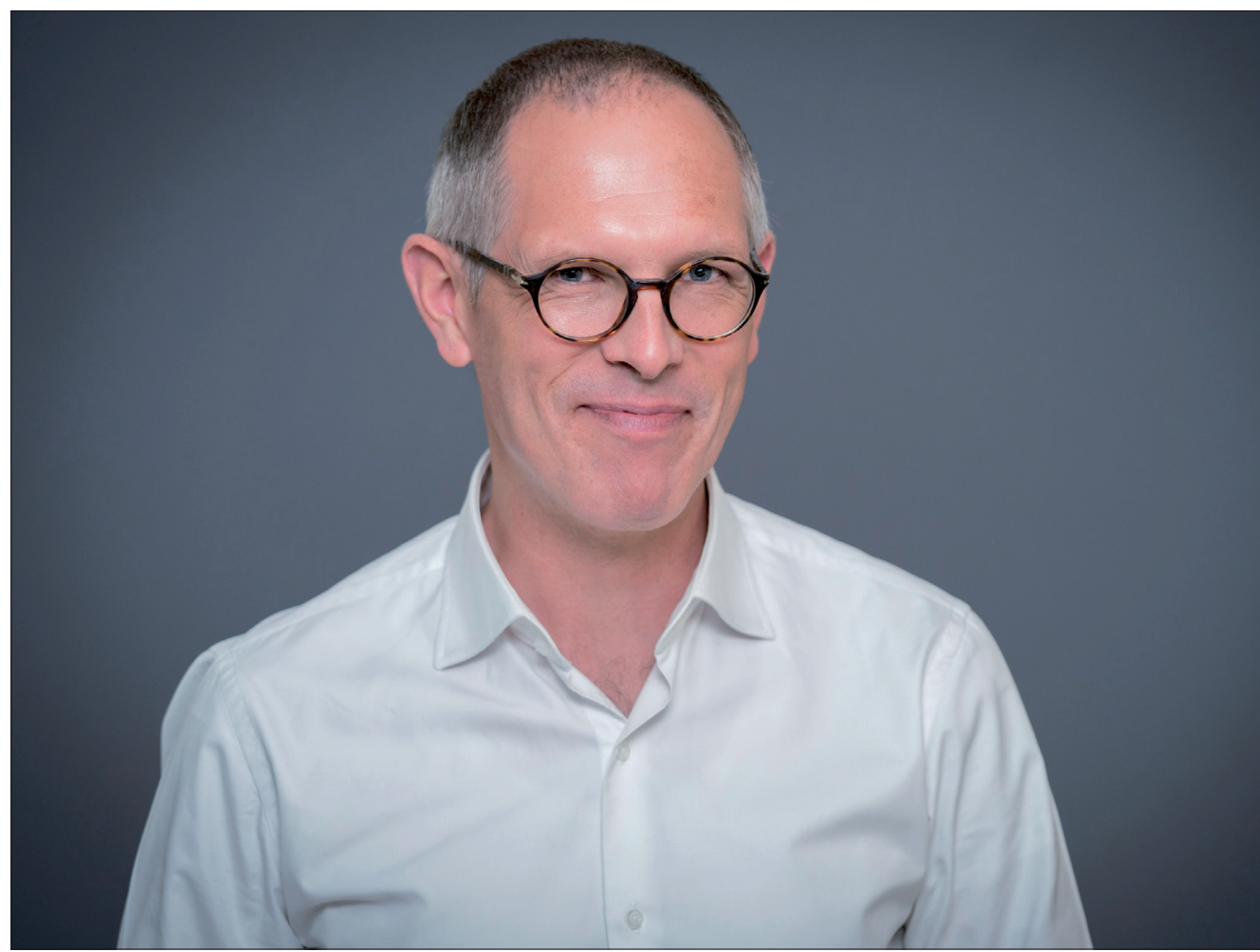

Jan Holmberg (c) Foto Göran Segeholm, 2017.

[KS] The Ingmar Bergman Foundation also controls the rights to Bergman's manuscripts being performed. What is the scale of the interest in staging Bergman's works in theatres or radio?

[JH] The interest is overwhelming! Over the last 3-4 years, we have an average of 5060 new Bergman productions for the stage (including radio) globally. It makes him one of the most performed Scandinavian playwrights (although probably less performed than Ibsen...). I am just now going through the statistics for this year, and however not entirely reliable, a conservative estimate says that some 500,000 people saw a play based on a Bergman script so far in 2018.

[KS] In what other ways does the foundation spread the knowledge about Ingmar Bergman?

[JH] We are mostly into facilitating others to spread knowledge by assisting and supporting documentaries, books, conferences and other events. But we are also actively working on, for example, the publication of Bergman's collected writings.

[KS] Ingmar Bergman's hundred-year jubilee in 2018 was celebrated worldwide. What is the foundation's role regarding this anniversary? 
[JH] We like to think of ourselves as the spider in the web... Surely, many projects (film retrospectives, theatre productions, conferences and exhibitions) have happened and are happening regardless of what we're doing, but we have actively helped and facilitated many of these activities, in Sweden and internationally. To be able to do this, we have gained financial support from the Swedish government, for which we are very grateful. As are, I am sure, all of those institutions and members of the public who have benefited from this grant.

[KS] In the feature picture of the anniversary, we can see Ingmar Bergman walking over the theatre stage. During his active work as a theatre director, Bergman staged plays by various playwrights. His favourite playwright was, however, August Strindberg. Why was Bergman so attached to this particular Swedish author?

[JH] Oh, that's a long story which could take up a book or two... But very briefly put, Strindberg was (and still is) Sweden's most famous and celebrated writer of all times. Bergman is a couple of generations behind (he was born a few years after Strindberg's death), but I think he saw himself as an heir to Strindberg in many ways. Thematically (the interest in family dynamics, the individual vs. the collective), aesthetically (sometimes stylistically brutal, sometimes tender - often ironic), and not least methodically (they were both extremely prolific and worked in various media).

[KS] You have recently published a book about Ingmar Bergman (Författaren Ingmar Bergman, Norstedts, 2018), where you explore the true nature of Bergman's texts. Could you introduce the most important of your findings?

[JH] Haha, another of those questions that merits a longer answer than possible... But a good one, of course! I'd say that the most important thing I found, is what an absolutely extraordinary writer Bergman was. I have systematically read all of his official writings (film scripts, articles, plays, books) and almost all of his survived private writings (letters, journals, notebooks) and I think that his means of expressions are masterful. His stories, yes, but also the minute details of his formulations (everything from the rhythm of his language to the metaphors he uses) make him one of our greatest writers, certainly one of the most underestimated ones (not least by himself).

[KS] During one period of Swedish film history, young Swedish filmmakers found Bergman's work suffocating, old fashioned, treating topics which were too personal and little committed. Is contemporary Swedish film somehow reflecting upon Ingmar Bergman's work today?

[JH] Yes, they had good reasons to... Bergman was indeed a towering figure in the Swedish cinema for a long time. That said, without him, the interest in our filmmakers would not have been what it was, and in that respect many of his colleagues - even the ones who opposed him - probably benefited from his existence. I think, however, that the younger generation is less concerned with Bergman, for better or worse. They want to do their thing, as they should. But I also see a renewed interest in Bergman's cinema, which has been rather neglected in his home country, where the person has stood 
in the way for his work. People have based their opinions on what he said in interviews rather than by watching the films. I have now good hope that his fellow Swedes actually study his work, rather than anything else. And that they will be as enthusiastic about it as so many others have been, and still are, in the rest of the world.

[KS] Ingmar Bergman is today viewed as a classical author especially with respect to his filmography. What do you yourself perceive as timeless in Ingmar Bergman's work?

[JH] Stylistically, I think Bergman himself worked very hard to accomplish this sense of timelessness. Though he perhaps not always succeeded, his films are characterised by a strong sense of being outside of time. They were regarded as 'old-fashioned' already when they were new! Now, of course, they are 'old-fashioned' (at least 'old') and have as such fared better than many of the films which have struggled to be 'contemporary'. Thematically, Bergman is of course interested in the big issues, which are always with us and as such timeless: our relations to each other, to ourselves and, whether we believe or not, to God.

[KS] What would you wish Ingmar Bergman for his birthday?

[JH] I think he has already received the best possible gift! That his work still concerns people, that people all over the world are still moved, stimulated and excited about his artistic work, whether as a filmmaker or a writer or both. 